\title{
Influence of Various Biochars on the Survival, Growth, and Oxidative DNA Damage in the Earthworm Eisenia Fetida
}

\author{
Won-Il Kim, ${ }^{1}$ Anitha Kunhikrishnan, ${ }^{1}$ Woo-Ri Go, ${ }^{1}$ Seon-Hee Jeong, ${ }^{1}$ Gyeong-Jin Kim, ${ }^{1}$ \\ Seul Lee, ${ }^{1}$ Ji-Hyock Yoo, ${ }^{1}$ Namjun $\mathrm{Cho}^{1}$ and Ji-Ho Lee ${ }^{2^{*}}$ \\ ${ }^{1}$ Chemical Safety Division, National Academy of Agricultural Science \\ Rural Development Administration, Jeonju, 565-851, Korea \\ ${ }^{2}$ Accident Prevention and Assessment Division, National Institute of Chemical Safety, Daejeon, 305-343, Korea
}

Received: 21 October 2014 / Revised: 28 November 2014 / Accepted: 23 December 2014

Copyright (c) 2014 The Korean Society of Environmental Agriculture

This is an Open-Access article distributed under the terms of the Creative Commons Attribution Non-Commercial License (http://creativecommons.org/licenses/by-nc/3.0) which permits unrestricted non-commercial use, distribution, and reproduction in any medium, provided the original work is properly cited.

\begin{abstract}
BACKGROUND: Biochar (BC) has a great potential for enhancing soil fertility and carbon sequestration while facilitating beneficial waste disposition. Therefore, it is essential to assess and mitigate any inadvertent consequences associated with soil biochar amendment. Earthworm activity is very vital in the soil system, yet there are a limited number of studies that have examined their impact resulting from biochar application to soil.

METHODS AND RESULTS: In this study, the survival, growth, reproductive tests, and oxidative DNA damage tests (measured by 8 -hydroxydeoxyguanosine $(8-\mathrm{OHdG})$ and catalase (CAT) activities) to assess the potential toxicity to earthworm Eisenia fetida in artificial soil amended with $\mathrm{BCs}$ were investigated. The BCs derived from perilla meal, sesame meal, and pumpkin seed were pyrolyzed at 300 and $550^{\circ} \mathrm{C}$, and then amended with soil at a rate of $5 \%$. All the earthworms survived, but lost weight compared to control soil after 28 day incubation period. Moreover, the $\mathrm{BC}$-amended soils did not significantly affect the cocoon numbers of earthworms. Slightly higher
\end{abstract}

\footnotetext{
*교신저자(corresponding author): Ji-Ho Lee

Phone: +82-10-2268-5513; Fax: 042-605-7065;

E-mail: jhlee76@korea.kr
}

concentrations of $8-\mathrm{OHdG}$ and CAT were observed in earthworms present in BC-treated soil than those in control soil. Furthermore, the $8-\mathrm{OHdG}$ concentrations in the soil amended with $\mathrm{BC}$ produced at $550^{\circ} \mathrm{C}$ were greater than those at $300^{\circ} \mathrm{C}$, and it slightly decreased as the incubation time increased.

CONCLUSION: These observations could be due to higher contents of toxic metal(loid)s and also higher $\mathrm{pH}$ in BCs pyrolyzed at $550^{\circ} \mathrm{C}$ than $300^{\circ} \mathrm{C}$. While $\mathrm{BC}$ is efficiently being used in agricultural fields, this study suggests that it is required to assess the unintended negative impacts of $\mathrm{BC}$ on soil ecosystems.

Key words: Biochar, Earthworm, Oxidative damage, Perilla meal, Pumpkin seed, Sesame meal

\section{Introduction}

Biochars (BCs) are products of thermal degradation of organic materials by pyrolysis (Lehmann and Joseph, 2009). The BCs derived from agricultural biomass wastes are increasingly regarded as beneficial materials for soil and environmental remediation (Lehmann et al., 2011). The BC-amended soil can improve soil fertility for crop production, carbon 
sequestration for mitigating the green house gas, and removal of various pollutants (Lehmann et al., 2006). Also, the BCs have been also shown to change the composition and abundance of biological community in soil (O'Neill et al., 2009). These effects depend on the BC feedstock and pyrolysis conditions (Chan et al., 2009; Gaskin et al., 2008) as well on the soil itself (Speir, 2008). Among the agricultural biomasses, the total biomasses of perilla, sesame, and pumpkin crops are amounted to be $167,427,117,563$, and 300,000 ton/year, respectively, in Korea (Hong et al., 2004).

Earthworms have been considered as the most representative soil fauna worldwide, since they perform many essential and beneficial functions in soil ecosystems, including decomposition, nutrient mineralization, and soil structure improvement (Edwards and Bohlen, 1996). Their ability to perform these functions can be inhibited upon exposure to harmful substances. Many ecotoxicological studies have used earthworms as a model system to assess the potentially toxic materials in soils (Amorim et al., 2005; He et al., 2007; Lanno et al., 2004; Lukkari and Haimi, 2005; Zhou et al., 2007). Earthworms are useful model organisms because their response to environmental disturbances can be assessed and related to environmental outcomes, including their avoidance behavior, enzyme activity level, growth rate, mortality, and reproduction patterns (Yeardley et al., 1996).

Several studies have focused on the beneficial effects of BCs on the crop growth, reduction of greenhouse gas emission, and removal of toxic compounds (Woolf et al., 2010; Carter et al., 2013). Nevertheless, the harmful materials released from pyrolyzed BC unintentionally may inhibit the soil organisms (Lehmann et al., 2011; Weyers and Spokas, 2011). Pyrolyzed BCs contain toxic metal(loid)s, PAHs, and dioxins with various isomers, which are associated with oxidative stress through accumulation of reactive oxygen stress (ROS) in cellular tissues (Stegeman and Lech, 1991; Lopez et al., 2006). Particularly, the toxic metal(loid)s are involved in accumulation of ROS caused by imbalance between oxidants and antioxidants during metabolism, thereby inducing cell toxicity as well as potential carcinogenesis (Shi et al., 2004). Malondialdehyde (MDA) as a biomarker of oxidative stress is an oxidation product generated by the interaction between ROS and polyunsaturated fatty acids (Song et al., 2012). There is, however, a lack of agreement whether various $\mathrm{BCs}$ lead to negative or positive impact on the potential toxicity of earthworms. Furthermore, only very few researchers have studied the potential impact of BCs in soil on the toxicity and oxidative damage in earthworm tissues.

Previous studies have shown different response of earthworms to biochar in soil. In some cases, earthworms exhibit a preference for soils amended with biochar (Chan et al., 2008); the liming potential of the biochars was suggested as a factor that influences this preference (Topoliantz and Ponge, 2005; Topoliantz et al., 2005; Liesch et al., 2010). Not all biochars are, however, preferred by earthworms; toxicity of biochar compounds to earthworms (Liesch et al., 2010) and insufficient moisture (Li et al., 2011) are other factors that influence earthworm preferences for certain biochar-amended soils. Also, both the application rate of biochar and the original feedstock used have been shown to affect the soil biota. Weyers et al. (2009) reported that application rates higher than $67 \mathrm{t} \mathrm{ha}^{-1}$ of biochar made from poultry litter had a negative impact on earthworm survival rates. They hypothesized that increased soil $\mathrm{pH}$ or salt levels may have been the reason for the observed reduced survival rates. Liesch et al. (2010) noted that earthworm activity was greater in soil amended with pine chip biochar than with poultry litter biochar. Recent work by Van Zwieten et al. (2010) has shown that earthworms preferred biochar-amended ferrosols over control soils, although they found no significant difference for calcarosols. The earthworm reports cited above using biochar highlights the complex dynamic interactions which can vary greatly with soil type, application rate, feedstock used, and the presence of toxic materials.

In order to develop appropriate recommendations for biochar application, the potential impacts on soil biota, specifically earthworms, need to be identified. The present study was undertaken to evaluate the effect of various BCs, i.e. perilla and sesame meals, and pumpkin seeds on the survival, growth, reproduction, and oxidative stress, measured by catalase (CAT) and 8-hydroxydeoxyguanosine (8-OHdG) activities on the earthworms.

\section{Materials and methods}

\section{Biochar preparation and characterization}

The BCs were produced from perilla and sesame meals, and pumpkin seed at two different temperatures 
$\left(300\right.$ and $550^{\circ} \mathrm{C}$ ) by modifying the procedure reported by Yang et al. (2010). Selected biomasses were air-dried, ground to pass through a less than $2 \mathrm{~mm}$ sieve, placed into porcelain crucibles with lids, and pyrolyzed for 3 $\mathrm{h}$ at 300 and $550^{\circ} \mathrm{C}$ under limited oxygen in a muffle furnace. The $\mathrm{pH}$ and electrical conductivity (EC) in pyrolyzed BCs were determined using end-over-end equilibration of soil with water at a ratio of $1: 5$ for an hour and measuring the solution with calibrated $\mathrm{pH}$ and conductivity meters (250A, Thermo Orion, Beverly, MA, USA). For proximate analysis, the contents of moisture, ash, mobile matter, and resident matter were measured by following the modified thermal analysis method suggested by McLaughlin et al. (2009). The moisture was determined by calculating the weight loss after heating the $\mathrm{BCs}$ at $105^{\circ} \mathrm{C}$ for $24 \mathrm{~h}$ to a constant weight. The ash contents were measured by heating the $\mathrm{BCs}$ in open-top crucibles at $700^{\circ} \mathrm{C}$ for $1 \mathrm{~h}$. Mobile matter was determined as the weight loss after heating in a covered crucible at $450^{\circ} \mathrm{C}$ for $30 \mathrm{~min}$. The resident matter was calculated by the difference in moisture, ash, and mobile matter. The contents of trace metal(loid)s in selected BCs were acid-digested with concentrated $\mathrm{HNO}_{3}$ for 5 days, filtered (Hyundai Micro Co., Ltd No. 52, Seoul, Korea), diluted, and analyzed by ICP-OES (GBC Scientific Ltd., Australia) using the modified procedure described in US EPA method 3051A (US EPA, 1995).

\section{Artificial soil preparation and incubation}

Artificial soil was prepared by mixing 10\% Sphagnum peat moss (previously sieved through 2 $\mathrm{mm}$ mesh), 20\% kaolin clay, and 68\% quartz sand as described by US EPA guideline (US EPA, 1996). 2\% calcium carbonate was added to adjust the soil $\mathrm{pH}$ to $6.5 \pm 0.5$, and moistened to $35 \%$ by weight with Milli$\mathrm{Q}$ ultrapure water. The pyrolyzed BCs at two temperatures were amended with $300 \mathrm{~g}$ soil at an application rate of $5 \%$, and incubated for a week to allow equilibration. All the treatments per experiment were performed in triplicates.

\section{Earthworm toxicity test}

\section{Growth and reproductive tests}

In this study, the earthworm Eisenia fetida was chosen, which is widely used as a model soil organism in research (Van Zwieten et al., 2010; Li et al., 2011). The earthworm subchronic toxicity test was conducted by following a modified protocol developed by US EPA
(US EPA, 1996). The earthworms were randomly selected in a range of $300-600 \mathrm{mg}$, and depurated on filter paper hydrated with ultrapure Milli-Q water for 24 h. Ten adult E. fetida earthworms were weighed and transferred to $500 \mathrm{~mL}$ glass jars, which contained the soil amended with $\mathrm{BCs}$ produced at 300 and $550^{\circ} \mathrm{C}$ at $5 \%$ application rate. These glass jars were covered in parafilm(with air holes) to prevent earthworm escape, and incubated at a temperature of $20 \pm 2{ }^{\circ} \mathrm{C}$, and relative humidity above $85 \%$ for 28 days in dark. The number of worms alive in each container was counted after 28 days. Growth was measured by weighing worms at the end of the exposure period, to determine the mean percentage growth of the population relative to the mean initial weight. Cocoons were collected at the end of the experiments by wetsieving the soil from each container.

\section{8-hydroxydeoxyguanosine (8-OHdG) and catalase} (CAT) activity measurement

The earthworms exposed to BC-treated soil were picked out, and depurated on a hydrated filter paper (Whatman ${ }^{\circledR}$, Brentford, UK).The earthworm tissue was homogenized by a moto-homogenizer (ART-MICCRA D-8, Mullheim, Germany) on ice with a cold buffer (i.e. $100 \mathrm{mM}$ potassium phosphate, $\mathrm{pH} 7.0,2 \mathrm{mM}$ EDTA) for CAT activity. For the measurement of $8^{-}$ OHdG as an indicator of oxidative DNA damage, the earthworm was also homogenized with cell extraction buffer (Invitrogen, Camarillo, CA, USA), $1 \mathrm{mM}$ phenylmethylsulfonyl fluoride (PMSF), and protease inhibitor cocktail (Amresco, Cochran Solon, $\mathrm{OH}$, USA). The homogenized samples were centrifuged at 13,000 rpm for $15 \mathrm{~min}$, and the supernatants were taken for CAT and 8-OHdG measurements at 0,10 , 20 days. The CAT activity was assayed by measuring the formaldehyde produced by the reaction of methanol with enzyme in the presence of $\mathrm{H}_{2} \mathrm{O}_{2}$. The amount of formaldehyde was determined using purpald as a chromogen at $595 \mathrm{~nm}$. One unit of CAT was defined as the amount of enzyme to cause the formation of $1 \mathrm{nmol}$ formaldehyde per min at $25^{\circ} \mathrm{C}$. Oxidative DNA damage test was performed using OxiSelect $^{\mathrm{TM}}$ Oxidative DNA damage ELISA Kit (Cellbiolabs, San Diego, CA, USA). Briefly, the supernatants were added to an $8-\mathrm{OHdG} / \mathrm{BSA}$ conjugate pre-absorbed EIA plate. After a brief incubation for 10 minutes, an anti-8-OHdG monoclonal antibody was added, followed by an HRP conjugated secondary 
Table 1. The $\mathrm{pH}$, electrical conductivity, and proximate analysis of various biochars derived from perilla, and sesame meals, and pumpkin seed at 300 and $550^{\circ} \mathrm{C}$

\begin{tabular}{cccccccccc}
\hline Biochars & $\mathrm{pH}$ & $\mathrm{pH}$ & $\begin{array}{c}\mathrm{EC} \\
(1: 5)\end{array}$ & $\begin{array}{c}\mathrm{EC} \\
(1: 5)^{\mathrm{a}} \\
(1: 5)\end{array}$ & $\begin{array}{c}\text { Yield } \\
(\%)\end{array}$ & $\begin{array}{c}\text { Moisture } \\
(\%)\end{array}$ & $\begin{array}{c}\text { Ash } \\
(\%)\end{array}$ & $\begin{array}{c}\text { Mobile } \\
\text { matter } \\
(\%)\end{array}$ & $\begin{array}{c}\text { Resident } \\
\text { matter } \\
(\%)\end{array}$ \\
\hline Perilla meal-300 & $8.80 \pm$ & $7.67 \pm$ & $0.22 \pm$ & $0.23 \pm$ & $58 \pm$ & $0.86 \pm$ & $13.50 \pm$ & $58.50 \pm$ & $\begin{array}{c}27.10 \pm \\
(\mathrm{mS} / \mathrm{cm})\end{array}$ \\
& 0.03 & 0.13 & 0.01 & 0.07 & 0.7 & 0.03 & 0.2 & 1.2 & 0.5 \\
Perilla meal-550 & $10.30 \pm$ & $7.96 \pm$ & $0.55 \pm$ & $0.22 \pm$ & $33 \pm$ & $1.03 \pm$ & $19.6 \pm$ & $47.50 \pm$ & $31.90 \pm$ \\
& 0.10 & 0.70 & 0.05 & 0.20 & 0.1 & 0.05 & 0.3 & 1.0 & 0.2 \\
Sesame meal-300 & $8.63 \pm$ & $7.58 \pm$ & $0.41 \pm$ & $0.30 \pm$ & $62 \pm$ & $1.52 \pm$ & $6.50 \pm$ & $56.00 \pm$ & $36.00 \pm$ \\
& 0.03 & 0.72 & 0.02 & 0.20 & 0.5 & 0.02 & 0.4 & 0.8 & 0.5 \\
Sesame meal-550 & $10.12 \pm$ & $8.18 \pm$ & $1.01 \pm$ & $0.43 \pm$ & $34 \pm$ & $0.50 \pm$ & $11.70 \pm$ & $42.50 \pm$ & $45.30 \pm$ \\
& 0.05 & 0.51 & 0.08 & 1.34 & 0.7 & 0.01 & 0.1 & 0.7 & 0.2 \\
Pumpkin seed-300 & $7.64 \pm$ & $7.18 \pm$ & $0.28 \pm$ & $0.59 \pm$ & $64 \pm$ & $1.09 \pm$ & $5.50 \pm$ & $68.30 \pm$ & $25.10 \pm$ \\
& 0.08 & 0.43 & 0.06 & 0.40 & 0.1 & 0.08 & 0.2 & 0.7 & 0.1 \\
Pumpkin seed-550 & $7.81 \pm$ & $7.68 \pm$ & $1.06 \pm$ & $0.37 \pm$ & $26 \pm$ & $0.72 \pm$ & $10.10 \pm$ & $41.30 \pm$ & $47.90 \pm$ \\
& 0.07 & 0.76 & 0.10 & 0.81 & 0.7 & 0.10 & 0.1 & 0.6 \\
\hline
\end{tabular}

a Measured values in artificial soil amended with 5\% biochar; Measured values are expressed as mean \pm SD of triplicates; The $\mathrm{pH}$ and $\mathrm{EC}$ values in control soil were $7.03 \pm 0.03$ and $0.18 \pm 0.08 \mathrm{mS} / \mathrm{cm}$, respectively.

Table 2. The contents of trace metal(loid)s in biochars derived from perilla, and sesame meals, and pumpkin seed at 300 and $550^{\circ} \mathrm{C}$

\begin{tabular}{cccccccc}
\hline Biochars & $\begin{array}{c}\mathrm{As} \\
(\mathrm{mg} / \mathrm{kg})\end{array}$ & $\begin{array}{c}\mathrm{Cd} \\
(\mathrm{mg} / \mathrm{kg})\end{array}$ & $\begin{array}{c}\mathrm{Cr} \\
(\mathrm{mg} / \mathrm{kg})\end{array}$ & $\begin{array}{c}\mathrm{Cu} \\
(\mathrm{mg} / \mathrm{kg})\end{array}$ & $\begin{array}{c}\mathrm{Ni} \\
(\mathrm{mg} / \mathrm{kg})\end{array}$ & $\begin{array}{c}\mathrm{Pb} \\
(\mathrm{mg} / \mathrm{kg})\end{array}$ & $\begin{array}{c}\mathrm{Zn} \\
(\mathrm{mg} / \mathrm{kg})\end{array}$ \\
\hline Perilla meal-300 & $\mathrm{ND}$ & $0.05 \pm 0.07$ & $4.11 \pm 0.01$ & $70.56 \pm 3.43$ & $7.69 \pm 0.16$ & $20.33 \pm 0.17$ & $163.04 \pm 14.53$ \\
Perilla meal-550 & $\mathrm{ND}$ & $1.86 \pm 0.02$ & $12.50 \pm 0.05$ & $131.60 \pm 2.20$ & $8.46 \pm 0.11$ & $20.61 \pm 0.05$ & $373.24 \pm 10.30$ \\
Sesame meal-300 & ND & $0.39 \pm 0.01$ & $4.20 \pm 0.36$ & $60.32 \pm 1.22$ & $8.94 \pm 0.11$ & $16.83 \pm 4.60$ & $149.92 \pm 17.52$ \\
Sesame meal-550 & ND & $2.77 \pm 0.22$ & $6.74 \pm 0.69$ & $103.84 \pm 17.51$ & $7.17 \pm 1.56$ & $16.14 \pm 3.86$ & $316.15 \pm 90.23$ \\
Pumpkin seed-300 & ND & ND & $3.01 \pm 1.98$ & $86.62 \pm 58.33$ & $23.87 \pm 6.10$ & $17.04 \pm 4.27$ & $181.26 \pm 11.86$ \\
Pumpkin seed-550 & ND & ND & $9.65 \pm 2.07$ & $91.20 \pm 2.48$ & $10.28 \pm 0.59$ & $13.81 \pm 2.77474 .52 \pm 42.69$ \\
\hline
\end{tabular}

Measured values are expressed as mean \pm SD of triplicates.

antibody. Oxidative DNA damage was assayed by measuring the $8-\mathrm{OHdG}$ content at $450 \mathrm{~nm}$.

\section{Statistical analysis}

All calculations and standard deviation between the replicates were done using the graphing software, SigmaPlot (version 10.0). Whether differences between the treatments were statistically significant was determined using Student's ttests at the $95 \%$ confidence level.

\section{Results and discussion}

\section{Characterization of biochars}

Some of the physico-chemical characteristics, i.e. $\mathrm{pH}$, EC, yield, moisture, ash content, mobile, and resident matters of $\mathrm{BCs}$ derived from perilla, sesame, and pumpkin seeds are shown in Table 1. The $\mathrm{pH}$ and $\mathrm{EC}$ values for $\mathrm{BC}$ produced at $550^{\circ} \mathrm{C}$ ranged from
7.81-10.30 and 0.55-1.06 $\mathrm{mS} / \mathrm{cm}$, respectively, which were higher than those at $300^{\circ} \mathrm{C}$. The BCs produced from perilla and sesame meals at $550{ }^{\circ} \mathrm{C}$ showed high $\mathrm{pH}$ values over 10.0, and it reduced to 7.96 and 8.18, respectively, when amended with artificial soil at an application rate of $5 \%$. Also, the $\mathrm{EC}$ values of $\mathrm{BCs}$ produced at $550^{\circ} \mathrm{C}$ were reduced to 0.22 and 0.43 $\mathrm{mS} / \mathrm{cm}$, respectively, when amended with soil. The proportion of yield and mobile matter in the selected BCs at $550^{\circ} \mathrm{C}$ were $1.2-2.5$ times lower than those at $300{ }^{\circ} \mathrm{C}$. In contrast, the ash and resident matter in BCs at $550{ }^{\circ} \mathrm{C}$ were increased to a maximum of two folds compared to those at $300^{\circ} \mathrm{C}$. The moisture content at both temperatures of BCs derived from perilla, and sesame meals, and pumpkin seed were similar. 
A

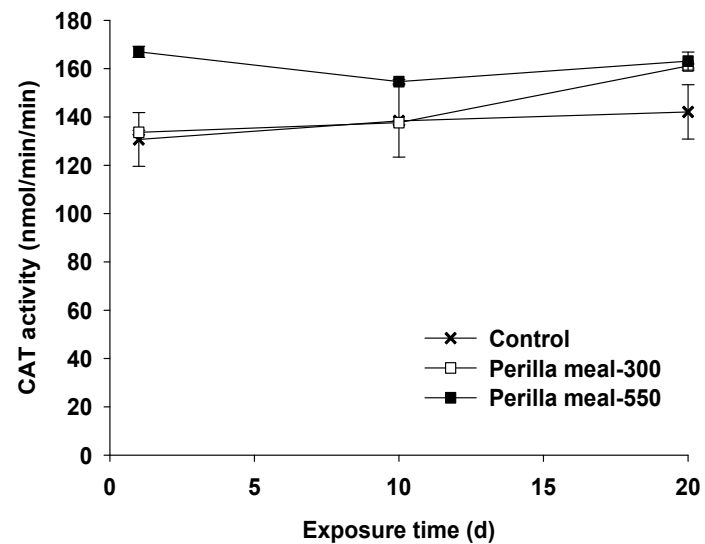

B

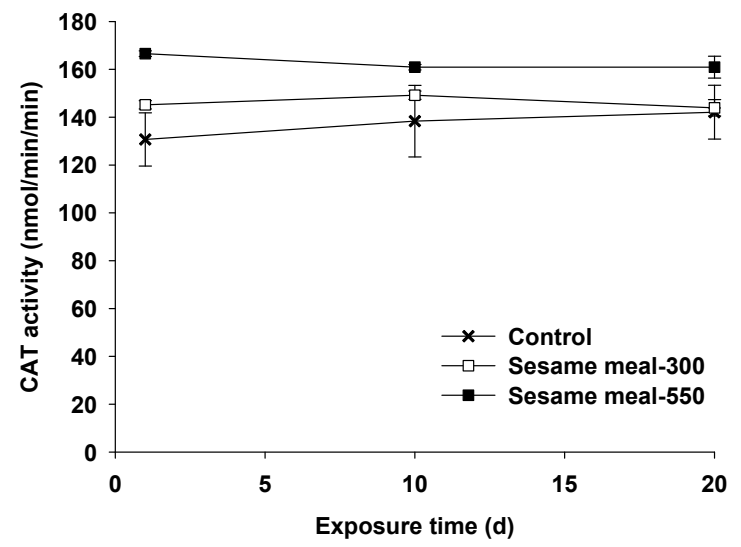

C

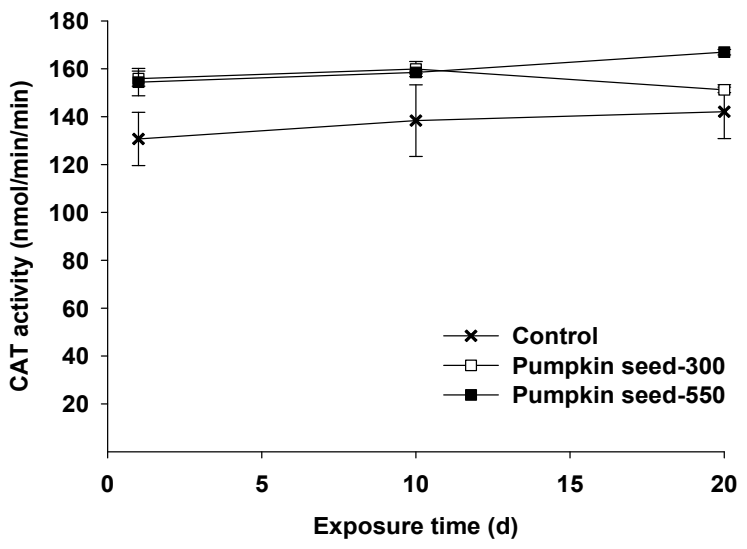

Fig. 1. Catalase measurements in earthworm tissues in control and soil amended with biochar produced from perilla meal (A), and sesame meal (B), and pumpkin seed (C) at 300 and $550^{\circ} \mathrm{C}$ during the 28 days incubation period. The catalase activity was estimated by measuring the amount of formaldehyde determined at $595 \mathrm{~nm}$, and each value was expressed as mean \pm standard deviation of triplicates.

\section{Trace metal(loid) concentrations}

The contents of trace metal(loid)s in BCs derived from perilla, and sesame meals, and pumpkin seed are shown in Table 2. The BCs produced at 300 and $550^{\circ} \mathrm{C}$ showed high contents of zinc $(\mathrm{Zn})$, copper $(\mathrm{Cu})$, chromium $(\mathrm{Cr})$, and cadmium $(\mathrm{Cd})$ in the range of $149.92-474.52 \mathrm{mg} / \mathrm{kg}, 60.32-131.60 \mathrm{mg} / \mathrm{kg}, 3.01-\sim 12.5$ $\mathrm{mg} / \mathrm{kg}$, and $0.05-2.77 \mathrm{mg} / \mathrm{kg}$, respectively. These contents were approximately 2-3 times higher in BCs pyrolyzed at $550^{\circ} \mathrm{C}$ than those at $300^{\circ} \mathrm{C}$. No significant difference in lead $(\mathrm{Pb})$ contents was observed in $\mathrm{BCs}$ produced at both temperatures. The arsenic (As) contents were not detected in BCs pyrolyzed at 300 and $550^{\circ} \mathrm{C}$. In pumpkin seed $\mathrm{BC}$, the contents of $\mathrm{Cd}$ were not detected and the $\mathrm{Ni}$ contents were two folds higher at $300^{\circ} \mathrm{C}$ rather than at $550^{\circ} \mathrm{C}$.

Effect of biochar on the growth, mortality, and cocoon production of earthworms

The survival, average weight loss, and cocoon numbers in the earthworms were determined after 28 days of exposure to soil amended with 5\% BC derived from perilla, and sesame meals, and pumpkin seed at 300 and $550^{\circ} \mathrm{C}$ (Table 3). All the worms exposed to BC-amended soil for 28 days survived. Average weight loss (\%) of E. fetida was slightly increased by the exposure of soil amended with $\mathrm{BC}_{550}$. Approximately, 2-fold average weight losses were observed in worms exposed to $\mathrm{BC}_{550}$ from perilla and sesame meals than $\mathrm{BC}_{300}$. The average weight losses of earthworms were in the range of $12.9-22.1 \%$ in perilla meal, 9.4-16.2 \% in sesame meal at 300 and 50 $0{ }^{\circ} \mathrm{C}$, respectively, and $17.6 \%$ in pumpkin seed at both temperatures. No significant difference in average weight loss was observed among the selected BCs ( $p$ $>0.05$ ). Cocoon numbers of $E$. fetida showed similar values in the ranges of $3.02 \pm 0.58-3.63 \pm 0.68$ for all the treatments. After the 28 days incubation period, there was a notable increase in the $\mathrm{pH}$ in soils amended with BCs. Liesch et al. (2010) also noticed an increase in $\mathrm{pH}$ after the earthworm toxicity test in the presence of pine chip and poultry litter biochars. They also observed mortality and weight loss in worms present in poultry litter BC amended soils, 
A

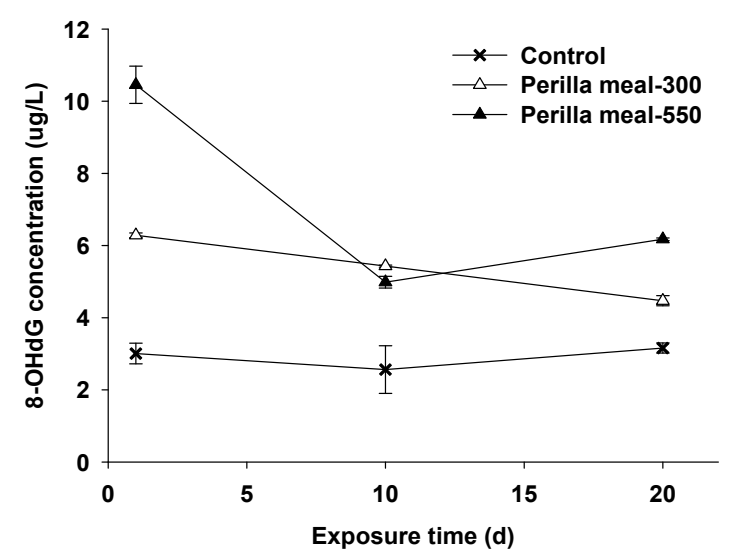

$\mathrm{C}$

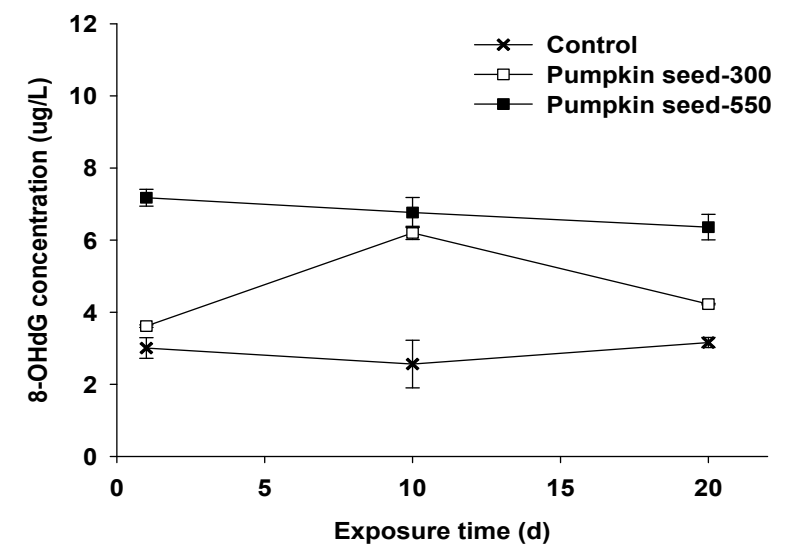

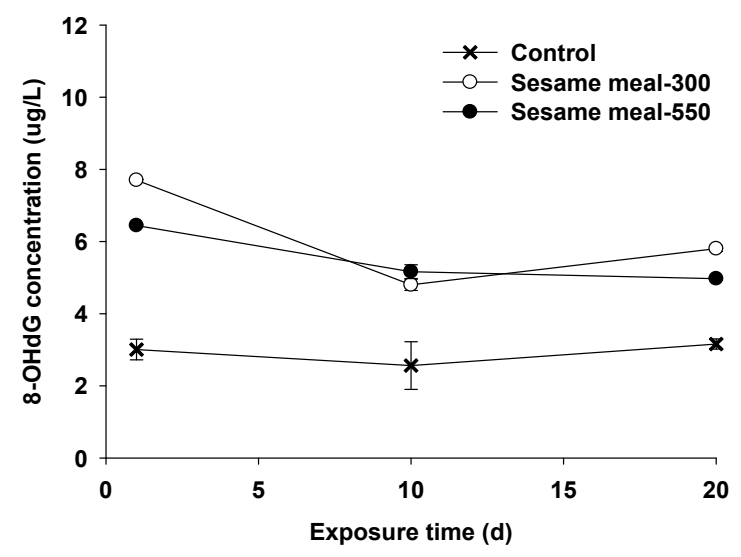

$\square-$ Pumpkin seed-300

Fig. 2. 8-hydroxydeoxyguanosine measurements in earthworm tissues in control and soils amended with biochar produced from perilla meal (A), and sesame meal (B), and pumpkin seed (C) at 300 and $550{ }^{\circ} \mathrm{C}$ during 28 days incubation period. Measured value indicates the mean \pm standard deviation of triplicates. Statistically sgnificant difference in $8^{-}$ hydroxydeoxyguanosine concentrations was not observed between control soil and biocharamended soil.

however, no significant effects in pine chip biochar treatment were recorded. Li et al. (2011) reported that BC mixture at 10 and $20 \%$ in artificial soil significantly increased weight loss compared to control, but did not show significant effects on reproduction.

\section{Enzyme activity measurements}

The CAT enzyme activity performed to assess the oxidative cellular damage of E. fetida due to ROS production were estimated in control and soil amended with $\mathrm{BC}_{550}$ during the 28 days exposure (Fig. 1). The worms exposed to BCs prepared from perilla and sesame meals showed slight induction of CAT activities, but time-dependent variations were

Table 3. The survival, average weight loss (\%), and cocoon numbers of earthworms and soil $\mathrm{pH}$ after 28 days exposure to soil amended with various biochars

\begin{tabular}{cccccc}
\hline Biochars & $\mathrm{pH}$ & Survival $(\%)$ & Initial weight $(\mathrm{g})$ & $\begin{array}{c}\text { Average weight } \\
\text { loss }(\%)\end{array}$ & $\begin{array}{c}\text { Cocoon } \\
\text { number/worm }\end{array}$ \\
\hline Control & - & 100 & $0.52 \pm 0.06$ & $6.54 \pm 0.06$ & $3.63 \pm 0.68$ \\
Perilla meal-300 & $7.81 \pm 0.03$ & 100 & $0.56 \pm 0.02$ & $12.95 \pm 0.03$ & $3.27 \pm 0.78$ \\
Perilla meal-550 & $8.32 \pm 0.06$ & 100 & $0.57 \pm 0.09$ & $22.12 \pm 0.11$ & $3.20 \pm 0.80$ \\
Sesame meal-300 & $7.78 \pm 0.05$ & 100 & $0.60 \pm 0.07$ & $9.42 \pm 0.07$ & $3.13 \pm 1.07$ \\
Sesame meal-550 & $8.51 \pm 0.08$ & 100 & $0.58 \pm 0.07$ & $16.21 \pm 0.08$ & $3.28 \pm 0.12$ \\
Pumpkin seed-300 & $7.32 \pm 0.03$ & 100 & $0.57 \pm 0.05$ & $17.63 \pm 0.04$ & $3.02 \pm 0.58$ \\
Pumpkin seed-550 & $7.86 \pm 0.04$ & 100 & $0.58 \pm 0.07$ & $17.62 \pm 0.06$ & $3.34 \pm 0.78$ \\
\hline
\end{tabular}


not observed. Similar CAT activities on earthworm tissues during the 28 days exposure were observed between control and soil amended with BCs produced at $300^{\circ} \mathrm{C}$. The CAT activities were enhanced from 160 to $170 \mathrm{nmol} / \mathrm{min} / \mathrm{mL}$ on E. fetida exposed to $\mathrm{BCs}$ produced at $550^{\circ} \mathrm{C}$. The earthworm tissues in $\mathrm{BC}_{550}$ and $\mathrm{BC}_{300}$ derived from pumpkin seed showed no significant differences $(p>0.05)$ in CAT activities, and only showed a slightly higher induction, to a maximum of $160 \mathrm{nmol} / \mathrm{min} / \mathrm{mL}$ than the control soil. Li et al. (2011) reported that superoxide dismutase (SOD) activity in earthworm tissue did not show significant differences in soil amended with $20 \%$ BC during the 14 days test $\mathrm{Li}$ et al. (2009) noticed increased catalase and cellulose activities in $\mathrm{Cd}$ - and $\mathrm{Pb}$-treated E.fetida which indicated toxicant induced DNA damage.

The 8-OHdG activity as a biomarker of oxidative DNA damage on the earthworm E. fetida in control and soil amended with BCs were measured during the 28 days exposure (Fig. 2). The results indicated increased levels of 8 -OHdG concentrations in worms in $\mathrm{BC}_{300}$ and $\mathrm{BC}_{550}$ soils than the control soil during the 28 days exposure. This indicated that enhanced $8^{-}$ OHdG concentration of E. fetida tissue exposed to BCs was associated with stimulated oxidative DNA damage. No significant difference in $8-\mathrm{OHdG}$ concentrations between $\mathrm{BC}_{300}$ and $\mathrm{BC}_{550}$ exposed worms was observed. However, the worms in soil amended with $\mathrm{BC}_{550}$ produced from perilla and sesame meals, and pumpkin seed increased the induction of $8-\mathrm{OHdG}$ with a range of $5-10 \mu \mathrm{g} / \mathrm{L}$, which slightly induced to a maximum of 2-folds compared to soil amended with $\mathrm{BC}_{300}(p>0.05)$. This may be due to the high contents of trace metal(loid)s in $\mathrm{BC}_{550}$ over $\mathrm{BC}_{300}$ (Table 2). Greater concentrations of 8-OHdG were observed by Li et al. (2011) in soil amended with BC produced from woodchips at $550^{\circ} \mathrm{C}$ than $300^{\circ} \mathrm{C}$. The $\mathrm{BCs}$ pyrolyzed over $500^{\circ} \mathrm{C}$ contain high concentrations of trace metal(loid)s, which are known to cause oxidative stress in earthworms (Weyers and Spokas, 2011).

\section{Conclusions}

This study examined the survival, growth, reproductive tests, and oxidative DNA damage tests on earthworm E. fetida in artificial soil amended with 5\% BCs pyrolyzed at 300 and $550^{\circ} \mathrm{C}$ from perilla and sesame meals, and pumpkin seed. Results indicated that weight loss in earthworms slightly increased in BCamended soil than the control after 28 days exposure. The 8-OHdG level and CAT activity increased in earthworms exposed to BCs-amended soil compared to control. Moreover, the $8-\mathrm{OHdG}$ concentrations in BCs amended soil at $500^{\circ} \mathrm{C}$ were greater than those at $300^{\circ} \mathrm{C}$. These observations were attributed to the high amounts of trace metal(loid)s and also an increased $\mathrm{pH}$ in BCs. This study suggests that it is necessary to investigate the long-term impact of $\mathrm{BCs}$ on earthworms in agricultural fields. As BC characteristics depend on the feedstock and conditions of pyrolysis, toxicity screening of BCs, prior to land application is recommended.

\section{Acknowledgment}

This study was supported by the 2013 Post Doctoral fellowship Program (PJ008650) at the National Academy of Agricultural Science, Rural Development Administration, Republic of Korea.

\section{References}

Amorim, M.J.B., Rombke, J., Soares, A.M.V.M., 2005. Avoidance behaviour of Enchytraeusalbidus. effects of benomyl, carbendazim, phenmedipham and different soil types, Chemosphere 59, 501-510.

Carter, S., Shackley, S., Sohi, S., Suy, T.B., Haefele, S., 2013. The impact of biochar application on soil properties and plant growth of pot grown lettuce (Lactucasativa) and cabbage (Brassicachinensis), Agronomy 3, 404-418.

Chan, K.Y., Van Zwieten, L., Meszaros, I., Downie, A., Joseph, S., 2008. Using poultry litter biochars as soil amendments, Soil Research 46, 437-444.

Chan, K.Y., Xu, Z., 2009. Biochar: nutrient properties and their enhancement, in: Lehmann, J., Joseph, S. (Eds), Biochar Environmental Management, Earthscan, London, Sterling, VA, pp. 67-84.

Edwards, C.A., Bohlen, P.J., 1996. Biology and Ecology of Earthworms, 50, Chapman \& Hall, New York, USA.

Gaskin, J.W., Steiner, C., Harris, K., Das, K.C., Bibens, B., 2008. Effect of lowtemperature pyrolysis conditions on biochar for agricultural use, Trans.ASABE 51, 2061-2069.

He, Q.L., Yan, Z.G., Wang, Q.H., Li, F.S., 2006. The application of earthworm avoidance test in ecological risk assessment of naphthalene-contaminated soils, $J$. Agro-Environ. Sci. 26, 538-543. 
Hong, S.G., 2004. Evaluation of agricultural biomass resource for renewable energy: biomass from orchards and non-paddy fields, J. Korean Society of Agric. Engineers 46, 85-92.

Lanno, R., Wells, J., Conder, J., Bradham, K., Basta, N., 2004. The bioavailability of chemicals in soil for earthworms, Ecotoxicol. Environ. Safety 57, 39-47.

Lehmann, J., Gaunt, J., Rondon, M. 2006. Biochar sequestration in terrestrial ecosystems-a review, Mitigation Adaptation Strategy Global Change, 11, 395-419.

Lehmann, J., Rillig, M.C., Thies, J., Masiello, C.A., Hockaday, W.C., Crowley, D., 2011. Biochar effects on soil biota-a review, Soil Biol. Biochem. 43, 1812-1836.

Li, D., Hockaday, W.C., Masiello, C.A., Alvarez, P.J., 2011. Earthworm avoidance of biochar can be mitigated by wetting, Soil Biol. Biochem. 43, 1732-1737.

Liesch, A.M., Weyers, S.L., Gaskin, J.W., Das, K.C., 2010. Impact of two different biochars on earthworm growth and survival, Annals Environ. Sci. 4, 1-9.

López, E., Arce, C., Oset-Gasque, M.J., Cañadas, S., González, M.P., 2006. Cadmium induces reactive oxygen species generation and lipid peroxidation in cortical neurons in culture, Free Radical Biology Medicine 40, 940-951.

Lukkari, T., Haimi, J., 2005. Avoidance of $\mathrm{Cu}$ and $\mathrm{Zn}-$ contaminated soil by three ecologically different earthworm species, Ecotoxicol. Environ. Safety 62, 35-41.

O'Neill, B., Grossman, J., Tsai, M.T., Gomes, J.E., Lehmann, J., Peterson, J., Neves, E., Thies, J.E., 2009. Bacterial community composition in Brazillian anthrosols and adjacent soils characterized using culturing and molecular identification, Microbial Ecology 58, 23-35.

Shi, H., Hudson, L.G., Liu, K.J., 2004. Oxidative stress and apoptosis in metal ion-induced carcinogenesis, Free Radical Biology Medicine 37, 582-593.

Song, H.M., Wang, H.Z., Xu, X.B., 2012. Overexpression of AtHsp90.3in Arabidopsisthaliana impairs plant tolerance to heavy metal stress, Biologia Plantarum, 56, 197-199.
Stegeman, J.J., Lech, J.J, 1991. Cytochrome P-450 monooxygenase systems in aquatic species: carcinogen metabolism and biomarkers for carcinogen and pollutant exposure, Environ. Health Perspectives 90, 101-109.

Topoliantz, S., Ponge, J.F., 2005. Charcoal consumption and casting activity by Pontoscolex corethrurus (Glossoscolecidae), Applied Soil Ecology 28, 217-224.

Topoliantz, S., Ponge, J.F., Ballof, S., 2005. Manioc peel and charcoal: a potential organic amendment for sustainable soil fertility in the tropics, Biology and Fertility of Soils 41, 15-21.

Van Zwieten, L., Kimber, S., Morris, S., Chan, K.Y., Downie A., Joseph, R.S., Cowie, A., 2010. Effects of biochar from slow pyrolysis of paper mill waste on agronomic performance and soil fertility, Plant and Soil 327, 235-246.

Weyers, S.L., Spokas, K.A., 2011. Impact of biochar on earthworm populations: a review, Applied and Environmental Soil Science p. 12, doi:10.1155/2011/ 541592.

Woolf, D., Amonette, J.E., Street-Perrott, F.A., Lehmann, J., Joseph, S., 2010. Sustainable biochar to mitigate global climate change, Nature communications 1, 1-9.

Yang, X.B., Ying, G.G., Peng, P.A., Wang, L., Zhao, J.L., Zhang, L.J., Yuan, P., He, H.P., 2010. Influence of biochars on plant uptake and dissipation of two pesticides in an agricultural soil. J. Agric. Food Chem. 58, 7915-7921.

Yeardley, R.B., Lazorchak, J.M., Gast, L.C., 1996. The potential of an earthworm avoidance test for evaluation of hazardous waste sites, Environ.Toxicol. Chem. 15, 1532-1537.

Zhou, S.P., Duan, C.Q., Fu, H., Chen, Y.H., Wang, X.H., $\mathrm{Yu}$, Z.F., 2007. Toxicity assessment for chlorpyrifoscontaminated soil with three different earthworm test methods, China J. Environ. Sci. 19, 854-858. 